\title{
Effects of processing and packaging on bioactive compounds of curriola jelly [Pouteria ramiflora (Mart.) Radlk.] during storage
}

\author{
Mariana Crivelari da CUNHA ${ }^{1}$, Jéssyca Santos SILVA ${ }^{1}$, Heloísa Helena de Siqueira ELIAS ${ }^{1}$, \\ Elisângela Elena Nunes CARVALHO ${ }^{1}$, Eduardo Valério de Barros VILAS BOAS ${ }^{1 *}$ (D)
}

\begin{abstract}
The objective herein was to evaluate the effect of processing, packaging type (with and without exposure to light) and storage time on the quality of functional attributes of jelly prepared from curriola pulp. The experimental design was a completely randomized $2 \times 5$ factorial design, with two levels of packaging (transparent and amber) and five storage periods (0, 3, 6, 9 and 12 months). In general, the processing of curriola pulp determined a slight increase in phenolic compounds and antioxidant activity and a reduction in vitamin $\mathrm{C}$ content of freshly prepared jelly. The amber package and storage time promoted higher retention of bioactive compounds, mainly gallic acid, besides reducing the percentage of jelly oxidation, determined by the $\beta$-carotene / linoleic acid antioxidant method. A reduction in phenolic compounds and vitamin $\mathrm{C}$ was observed, which caused a reduction in the antioxidant capacity of curriola jelly. Of the five phenolic compounds identified in freshly prepared curriola jelly, gallic acid was identified as the major compound. In addition, the use of amber packaging, which prevents the incidence of light, may favor the maintenance of bioactive compounds during storage period of curriola jelly under environmental conditions.
\end{abstract}

Keywords: Pouteria ramiflora (Mart) Radlk; shelf life; antioxidant capacity; liquid chromatography; phenolic compounds.

Practical Application: Adding value and exploring the functional potential of exotic fruit.

\section{Introduction}

The term Cerrado is commonly used to describe the set of ecosystems (savannas, forests, fields, and galley forests) that occur in the central region of Brazil. It is considered the second largest biome in the country, occupying about $25 \%$ of the national territory. However, in the last 30 years, progressive mechanization and deforestation have contributed to the destruction of about $40 \%$ of the natural vegetation (Geöcze et al., 2013; Roesler et al., 2008). Therefore, it is important and urgent to search for economically viable means of using the resources, for example, using fruit species for the production and development of new food products, to avoid the degradation of natural vegetation, disseminate knowledge, and raise awareness about the importance of preserving this biome.

Pouteria ramiflora (Mart.). Radlk is a species with fruits popularly known as "curriola," "curiola," "guapeva pilosa," or "grão-de-galo" (Perfeito et al., 2005; Rodrigues et al., 2017). It is highly possible to develop new food products, such as jellies, from this fruit and commercialize an attractive product that has functional, nutritional properties and is sensorially well-accepted. Moreover, the useful life of the fruit is extended by processing and without the use and/or addition of preservatives (Viana et al., 2012).

Curriola is widely used in popular medicine for the treatment of hyperlipidemias (Silva et al., 2010), and it has anti-inflammatory and antinociceptive (Fontes et al., 2009), antimicrobial and antifungal properties (Silva et al., 2009) and antioxidant potential
(Morzelle et al., 2015; Silva et al., 2009). However, there is limited information on the content and profile of phenolic compounds and antioxidant activities of the fruit and processed product. It is important to evaluate how processing affects the content of bioactive compounds and associated antioxidant activity because the effects of jelly processing on the content of these compounds are unclear and present contradictory conclusions.

The growing demand for processed plant products whose quality must be maintained during storage depends on appropriate packaging. To minimize losses of vitamins and compounds susceptible to photodegradation reactions, it is necessary to use packaging that blocks the incidence of light to avoid the degradation of food constituents (Azeredo et al., 2012; Miranda et al., 2012). Thus, suitable packaging of the jelly with a barrier to light incidence would probably positively affect the preservation of bioactive compounds of the processed product during storage. A previous bibliographical survey indicated that no scientific study on the phenolic compounds and antioxidant activity profile of curriola jelly packed in transparent and amber packaging and stored for 12 months has been published.

The purpose of this study was to prepare a jelly by using curriola pulp as the raw material and verify the effects of processing, packaging (transparent and amber), and storage period (0, 3, 6, 9 and 12 months) on the antioxidant activity and bioactive compounds of curriola jelly. 


\section{Materials and methods}

\subsection{Raw material}

Curriola pulp was acquired by the company Pureza Frutas do Brasil $^{\circledR}$, Aragarças - Goiás. The pulp was packed in polyethylene bags with a capacity of $1 \mathrm{~kg}$ and stored $-18^{\circ} \mathrm{C}$ until processing.

\subsection{Jelly formation}

According to conventional jelly formulations, the pulp and commercial sugar (1:1) and 1\% pectin were measured (Brasil, 1978). For jelly preparation, $5 \mathrm{~kg}$ of pulp, $50 \mathrm{~g}$ of commercial pectin (1\% in relation to sugar), $5 \mathrm{~kg}$ of crystal sugar (União ${ }^{\circledR}$ ), and $1 \%$ citric acid were used in a single batch on the same day. Initially, one-third of the sugar was added to the boil under constant stirring, and then commercial pectin $\left(\operatorname{Vetec}^{\circledR}\right)$ and the rest of the sugar were added and allowed to boil to the concentration of $67.5 \%$ solids, with no addition of preservatives. The cooking time was 45 minutes. After processing, the product was packed in pre-sterilized glass containers $\left(100^{\circ} \mathrm{C}\right.$ for $\left.15 \mathrm{~min}\right)$ with a capacity of $50 \mathrm{~mL}$ each. The containers were hermetically closed with internally varnished metal closures and inverted for $5 \mathrm{~min}$. Immediately afterwards, the containers were immersed in boiling water for $10 \mathrm{~min}$ and then cooled. The curriola jelly was stored under ambient conditions $\left(20.8^{\circ} \mathrm{C} \pm 2.8\right.$ and $69.6 \%$ $\mathrm{RH} \pm 10.51)$ until further analyses, which occurred every 3 months during 1 year of storage.

\subsection{Chemical analyses}

Preparation of the extract for determination of phenolic compounds and antioxidant activity

To evaluate antioxidant activity, we used the methodology described by Larrauri et al. (1997). First, $20 \mathrm{~mL}$ of $50 \%$ (v/v) methyl alcohol was added to $2.5 \mathrm{~g}$ of each sample, and the solution was homogenized and allowed to stand for $1 \mathrm{~h}$ at room temperature and protected from the light. Then, the mixture was centrifuged at $8.832 \times \mathrm{g}$ for $15 \mathrm{~min}$. The supernatant was transferred to a $50 \mathrm{~mL}$, and $20 \mathrm{~mL}$ of $70 \%(\mathrm{v} / \mathrm{v})$ acetone was added to the residue. The solution was homogenized and allowed to stand for $1 \mathrm{~h}$ at room temperature and protected from the light and then centrifuged at $8.832 \times \mathrm{g}$ for $15 \mathrm{~min}$. The supernatant was collected and mixed with the first supernatant, and the volume completed to $50 \mathrm{~mL}$ with distilled water. The extracts obtained were used for the determination of antioxidant activity and total phenolic, in spite of the methods used.

\section{Determination of vitamin $C$ content, total phenolic and antioxidant activity}

The vitamin $\mathrm{C}$ analysis was performed using the colorimetric method with 2,4-dinitrophenylhydrazine (Strohecker \& Henning, 1967 ) and the results were expressed as mg of ascorbic acid $100 \mathrm{~g}^{-1}$ sample.

The total phenolic content was determined according to the method adapted from Folin-Ciocalteau (Waterhouse, 2002) and by Fast Blue BB methodology, according to the method described by Medina (2011). The results were expressed as mg of gallic acid $100 \mathrm{~g}^{-1}$ sample.

The following methods were used to determine the antioxidant activity: (i) ABTS method conducted according to the methodology described by Brand-Williams et al. (1995) and the results expressed in $\mu \mathrm{mol}$ Trolox $\mathrm{g}^{-1}$ sample; (ii) DPPH method carried out according to the methodology described by Brand-Williams et al. (1995) and the results IC $_{50}$ expressed in $\mathrm{mg} \mathrm{mL}^{-1}$ of DPPH; (iii) $\beta$-carotene/linoleic acid method used according to the methodology described in Miller (1971), and the results expressed as percent inhibition of oxidation; (iv) FRAP method performed according to the methodology described by Pulido et al. (2000) and the results expressed in $\mu \mathrm{M}$ of ferrous sulfate $\mathrm{g}^{-1}$ sample; (v) Method of formation of the phosphomolybdenum complex conducted according to the methodology described by Prieto et al. (1999) and the results expressed as percentage of antioxidant activity.

\section{Preparation of the extract for determination of the phenolic compound profile}

Extracts for the identification of phenolic compounds by using chromatography were prepared according to the methodology described by Ramaiya et al. (2013). For extraction, $2.5 \mathrm{~g}$ of the sample, homogenized in $20 \mathrm{~mL}$ of $70 \%$ (v/v) HPLC-grade methanol, were maintained for $1 \mathrm{~h}$ in an ultrasonic bath at room temperature. The obtained extract was centrifuged at $8.832 \times \mathrm{g}$ for $15 \mathrm{~min}$ at $4{ }^{\circ} \mathrm{C}$ and filtered using filter paper with $14 \mu \mathrm{m}$ porosity. For sample injection, the extracts were again filtered using $0.45 \mu \mathrm{m}$ porous membrane filters.

\section{Determination of the phenolic compound profile}

Quantification and identification of the phenolic compounds were performed using a high-efficiency liquid chromatograph (HPLC-DAD/UV-Vis; Shimadzu Corporation, Kyoto, Japan) equipped with four high-pressure pumps (model LC-20AT) and a diode array detector (model SPD-M20A), degasser (model DGU-20A5), CBM-20A interface, and CTO-20AC oven and automatic sampler (model SIL-20A). Separations were performed using a Shimadzu Shim-pack ODS GVP-C18 (4.6 × $250 \mathrm{~mm}$, $5 \mathrm{~mm}$ ) attached to a pre-column (Shimadzu-pack ODS GVP-C18, $4.6 \times 10 \mathrm{~mm}, 5 \mu \mathrm{m})$. The mobile phase consisted of $2 \%(\mathrm{v} / \mathrm{v})$ acetic acid in deionized water (mobile phase A) and 70:28:2 (v/v/v) methanol:water:acetic acid (mobile phase B) at a flow rate of $1.0 \mathrm{~mL} \mathrm{~min}^{-1}$ with a gradient elution program and run time of $60 \mathrm{~min}$. The injection volume was $20 \mu \mathrm{L}$. The analyses were performed at $15^{\circ} \mathrm{C}$. The phenolic compounds were detected at $280 \mathrm{~nm}$. The standard solutions were diluted in methanol, and the calibration curves were obtained from injections of 10 different concentrations in duplicate. The phenolic compounds were identified by comparing the retention times with the standards (gallic acid, catechin, chlorogenic acid, caffeic acid, ferulic acid, trans-cinnamic acid, vanillin, rutin, quercetin, $m$-coumaric acid, $p$-coumaric acid, $o$-coumaric acid, and resveratrol). The results were expressed as $\mathrm{mg}$ of the phenolic compound $100 \mathrm{~g}^{-1}$ of the sample. 


\subsection{Experimental design}

A completely randomized $2 \times 5$ factorial design was used, with two packing levels (transparent and amber) and five storage periods (0, 3, 6, 9 and 12 months). Four replications were performed. For the chromatographic analysis, identification, and profile of the phenolic compounds, the same statistical design was used, but with only three replicates.

\subsection{Statistical analysis}

The statistical analysis were performed using the SISVAR software (Ferreira, 2011). After analysis of variance, the polynomial regression models were selected on the basis of the significance of the $\mathrm{F}$ test of each model and their determination coefficients $\left(\mathrm{R}^{2}\right)$. Principal Component Analysis (PCA) was used to understand the similarity between antioxidant tests. Analyses were performed using the CHEMOFACE software (Nunes et al., 2012).

\section{Results and discussion}

\subsection{Effects of processing on the bioactive compounds and antioxidant capacity}

Table 1 shows the vitamin $C$ and total phenolic compound contents (Folin-Ciocalteau and Fast Blue BB) and antioxidant activity [ABTS, DPPH, $\beta$-carotene/linoleic acid, iron-reducing power (FRAP) and phosphomolybdenum complex] of the curriola pulp and freshly prepared jelly.

The results showed that, in general, curriola pulp processing promoted an increase in phenolic compound contents and antioxidant activity (FRAP and phosphomolybdenum complex), as well as reduction in the vitamin $\mathrm{C}$ content in the freshly prepared jelly. The results are associated with the heat treatment (cooking) that favors the concentration of phenolic compounds, due to evaporation of part of the water during the jelly processing. According to Kim et al. (2006), heating of grape seed extract at $50{ }^{\circ} \mathrm{C}$ facilitated the release of phenolic compounds and, thus promoted an increase in the amount of bioactive compounds and, consequently, antioxidant capacity. Thus, the increase in temperature and disintegration of the plant tissue promoted by the heating can increase the bioavailability of phenolic compounds. The reduction of vitamin $\mathrm{C}$ after processing can be explained, by the fact that ascorbic acid is a thermolabile compound that, in its reduced form, can be easily oxidized during processing (pasteurization, cooking, immersion, dewatering, and convection drying) and may be affected by storage conditions and duration (Bertin et al., 2016).

The vitamin C content of curriola pulp (Table 1) is similar to the results reported by Morzelle et al. (2015), corresponding to $50.99 \pm 1.28 \mathrm{mg}$ of ascorbic acid $100 \mathrm{~g}^{-1}$ in the fruit. After processing, the freshly prepared jelly showed a reduction in ascorbic acid content corresponding to $26 \%$. This reduction, according to Gu et al. (2018), is caused by the oxidation of vitamin $\mathrm{C}$ and formation of compounds from non-enzymatic darkening reactions, such as hydroxymethylfurfuraldehyde (HMF), followed by polymerization reactions or degradation processes for sugar reduction. According to Kirk (1984), the loss of vitamin C during food processing is directly dependent on environmental factors (temperature, time, and oxygen concentration) and constituents present in the food (acidity and water activity).

According to Table 1, the Folin-Ciocalteau method overestimated the phenolic compound contents in the freshly prepared pulp and jelly samples; however, the processing positively influenced the increase in polyphenols in the product. Similar results, with the Folin-Ciocalteau method, have been reported by Kim et al. (2006), who evaluated the phenolic content of grape seed extracts after thermal treatments and Chamorro et al. (2012) who studied grape seed extracts and grape under different heating conditions (dry and moist heat). Therefore, thermal treatment can cause the rupture of the plant cell wall and, thus, increase the extraction process of insoluble phenolic compounds and inactivate enzymes that degrade polyphenols, preserving them (Raupp et al., 2011).

Thus, according to the results (Table 1), the effects of processing caused an increase in the antioxidant properties. According to Raupp et al. (2011) and Siddhuraju \& Manian (2007), this increase can be attributed to the formation of products of the non-enzymatic darkening reaction (Maillard reaction) or degradation processes during sugar reduction and HMF formation that have a high antioxidant capacity verified using different methods, as well as it being directly related to the polyphenol concentration increase in the freshly prepared jelly, due to the concentration by heat. Similar results have been reported by Li et al. (2017), Ozcan \& Uslu (2017), and Papoutsis et al. (2017) (baking, microwave irradiation, and roasting) in conventional fruits (orange and guava) and lemon

Table 1. Mean values of the determination of bioactive compounds of the curriola pulp and freshly prepared curriola jelly.

\begin{tabular}{|c|c|c|}
\hline Bioactive compounds and antioxidant capacity & Curriola pulp ${ }^{1}$ & Curriola jelly $^{2}$ \\
\hline Vitamin $\mathrm{C}\left(\mathrm{mg}\right.$ of ascorbic acid $\left.100 \mathrm{~g}^{-1}\right)$ & $44.01 \pm 1.23$ & $32.31 \pm 1.03$ \\
\hline Total phenolic mg of (EAG) $100 \mathrm{~g}^{-1 *}$ & $121.55 \pm 1.36$ & $141.06 \pm 11.10$ \\
\hline Fast Blue (mg of gallic acid $100 \mathrm{~g}^{-1}$ ) & $29.16 \pm 3.47$ & $28.40 \pm 5.75$ \\
\hline $\operatorname{ABTS}\left(\mu \mathrm{mol} \text { trolox g }{ }^{-1} \text { sample }\right)^{\star}$ & $254.56 \pm 22.79$ & $248.01 \pm 7.06$ \\
\hline $\mathrm{DPPH} \mathrm{IC}_{50}\left(\mathrm{mg} \mathrm{mL}^{-1} \text { of sample }\right)^{*}$ & $16.30 \pm 2.39$ & $15.33 \pm 4.37$ \\
\hline Carotene/linoleic acid method (\% inhibition of oxidation) & $7.99 \pm 0.01$ & $7.18 \pm 1.43$ \\
\hline FRAP $\left(\mu \mathrm{M} \text { of ferrous sulfate } \mathrm{g}^{-1} \text { sample }\right)^{*}$ & $96.75 \pm 10.97$ & $131.78 \pm 3.89$ \\
\hline Phosphomolybdenum complex ( $\mathrm{mg}$ of ascorbic acid $100 \mathrm{~g}^{-1}$ ) & $419.92 \pm 101.87$ & $559.51 \pm 203.21$ \\
\hline
\end{tabular}

${ }^{1}$ Data presented as mean \pm standard deviation of three repetitions; ${ }^{2}$ Data presented as mean \pm standard deviation of four repetitions of the initial time samples. ${ }^{\star}$ EAG: equivalent to gallic acid; ABTS: antioxidant activity by the 2,2'-azino-bis (3-ethylbenzothiazoline-6-sulfonic acid) diammonium salt method; DPPH: antioxidant activity by the 2,2-diphenyl-1picrylhydrazyl method; FRAP: antioxidant activity by the Ferric Reducing Antioxidant Power method. 
pomace, respectively, contradicting the results described by Sun et al. (2017) and Al Juhaimi et al. (2018) in pear and sweet potato seeds.

Therefore, the changes in antioxidant capacity and total phenolic content reported in this study may contribute to the information on the effects of thermal processing and heat stability of bioactive compounds in non-conventional fruits.

The phenolic profiles of the pulp and jelly are presented in Table 2.

In this study, among the compounds identified in the curriola pulp, the gallic acid content was the highest $\left(5.659 \pm 0.881 \mathrm{mg} 100 \mathrm{~g}^{-1}\right)$. Among the identified phenolic compounds, vanillin, chlorogenic acid, caffeic acid, ferulic acid and $p$-coumaric acid had concentrations

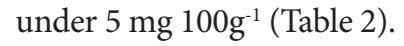

With the exception of ferulic acid, the other 5 phenolic compounds identified in the pulp were also identified in the freshly prepared curriola jelly and gallic acid was the major compound $\left(3.162 \pm 0.230 \mathrm{mg} 100 \mathrm{~g}^{-1}\right)$. The concentrations of the identified phenols in the jelly were lower than those in the pulp, reflecting the processing. The reduction in the concentrations of the phenolic compounds identified in the freshly prepared jelly can be explained by the effects of processing duration and temperature, which may have favored the loss of these phenolic constituents by degradative and/or oxidative processes.

\subsection{Effects of storage on the bioactive compounds and antioxidant capacity}

The storage period had a significant effect on the total phenolic and vitamin $\mathrm{C}$ contents and antioxidant activity of the curriola jelly, which were determined using the ABTS, DPPH, and FRAP methods. A significant interaction $(p<0.05)$ between storage duration and packaging was observed for the antioxidant activity determined by the $\beta$-carotene/linoleic acid method. The antioxidant activity determined by the phosphomolybdenum method was not influenced by packaging and storage. The adequacy of the mathematical adjustments $\left(\mathrm{R}^{2}\right)$, between 72 and $98 \%$, is explained in Figure 1.

Vasco et al. (2008) analyzed the total phenolic content by using the Folin-Ciocalteau method of 17 fruits from Ecuador and classified them into 3 categories: (i) low (<100 mg (EAG) $\left.100 \mathrm{~g}^{-1}\right)$, (ii) (100-500 mg (EAG) $100 \mathrm{~g}^{-1}$ ), and high (> $500 \mathrm{mg}$ (EAG) $\left.100 \mathrm{~g}^{-1}\right)$. Therefore, the pulp and jelly can be classified as intermediate sources of polyphenols (Table 1 and Figure 1).

In Figure 1, the content of phenolic compounds determined by 2 different methodologies (Folin-Ciocalteau and Fast Blue BB) significantly reduced $(p<0.05)$, average of $31 \%$ after 12 months of storage, and the models adjusted using the quadratic order can be explained by the decline in polyphenol content during the storage period. This is due to the storage conditions (exposed to environmental conditions) and product degradation from the non-enzymatic darkening reaction, which contributed to the reduction of the polyphenols. The mathematical model (quadratic order) that was adjusted for the phenolic compound contents determined using the Folin-Ciocalteau method was consistent with the results reported by Damiani et al. (2012a) for the storage of mixed araçá (Psidium guineensis Sw.) and marolo (Annona crassiflora Mart.) jam.

In general, plant products may be classified into 3 categories



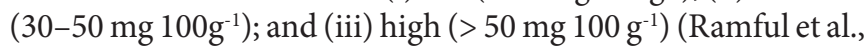
2011). Therefore, the pulp and jelly had a vitamin $C$ content that varied from low to medium throughout the storage period, according to this classification (Table 1 and Figure 1).

The vitamin $\mathrm{C}$ content throughout the storage period ranged from 32.27 to $15.54 \mathrm{mg}$ ascorbic acid $100 \mathrm{~g}^{-1}$, a reduction corresponding to $52 \%$. This result may be due to oxidative processes that affect the ascorbic acid content, a biologically active, thermolabile compound that is reversibly oxidized to 1-dehydroascorbic acid, which forms 2,3-diketogluconic acid through hydrolysis and undergoes reactions of (HMF), recognized as an indicator of deterioration in quality due to thermal processing and/or long storage periods in a wide range of foods containing high carbohydrate contents (Aslanova et al., 2010; Touati et al., 2014; Zulueta et al., 2013). In contrast, Damiani et al. (2012a) observed that the vitamin $C$ content showed a significant decline $(p<0.05)$ and was detectable up to the $4^{\text {th }}$ month of storage of mixed araçá and marolo jam.

The antioxidant activity of the curriola pulp during storage, determined by ABTS, DPPH, and FRAP methods, conformed to the quadratic model (Figure 1). A decline in the antioxidant

Table 2. Quantification and identification by HPLC-DAD/UV-Vis of phenolic compounds of curriola pulp and curriola jelly soon after processing.

\begin{tabular}{|c|c|c|c|}
\hline Phenolic compounds & Retention time (min) & Curriola pulp ${ }^{1}\left(\mathrm{mg} 100 \mathrm{~g}^{-1}\right)$ & Curriola jelly $^{2}\left(\mathrm{mg} 100 \mathrm{~g}^{-1}\right)$ \\
\hline 1. Gallic acid & 6.65 & $5.659 \pm 0.881$ & $3.162 \pm 0.230$ \\
\hline 2. Catechin & 10.49 & - & - \\
\hline 3. Chlorogenic acid & 12.19 & $1.364 \pm 0.262$ & $0.431 \pm 0.042$ \\
\hline 4. Caffeic acid & 14.38 & $1.304 \pm 0.286$ & $0.447 \pm 0.047$ \\
\hline 5. Vanillin & 16.80 & $1.368 \pm 0.272$ & $0.248 \pm 0.015$ \\
\hline 6. $p$-coumaric acid & 20.65 & $0.311 \pm 0.057$ & $0.044 \pm 0.005$ \\
\hline 7. Ferulic acid & 23.57 & $0.579 \pm 0.103$ & - \\
\hline 8. $m$-coumaric acid & 25.95 & - & - \\
\hline 9. o-coumaric acid & 32.35 & - & - \\
\hline 10. Resveratrol & 36.73 & - & - \\
\hline 11. trans-cinnamic acid & 50.43 & - & - \\
\hline
\end{tabular}

${ }^{1}$ Data presented as mean \pm standard deviation of two repetitions; ${ }^{2}$ Data presented as mean \pm standard deviation of three repetitions of initial time samples. 

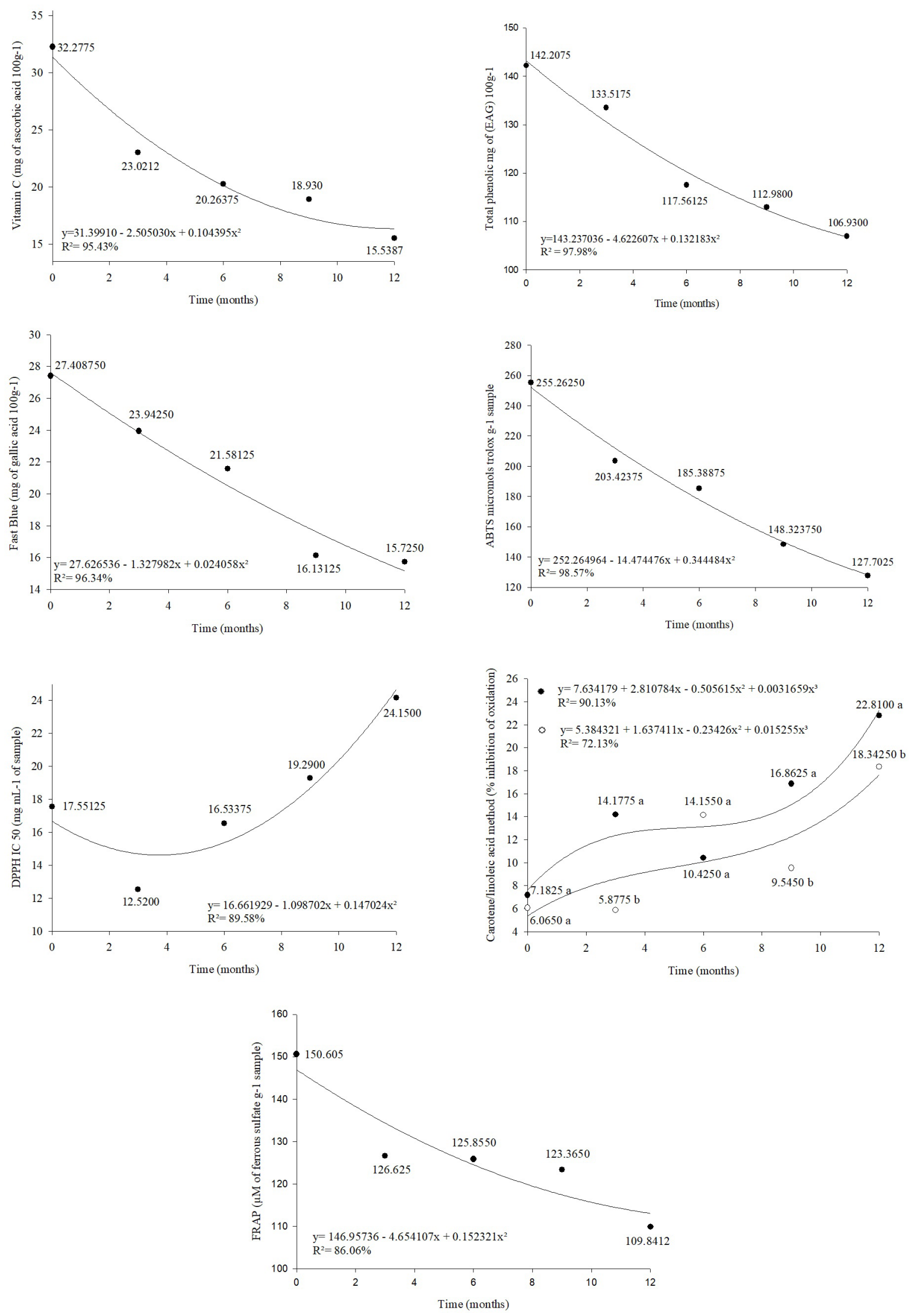

Figure 1. Models of adjustments made in the phenolic compounds (Folin-Ciocalteau and Fast Blue) analyzes, antioxidant activity [ABTS, $\mathrm{DPPH}$, iron reducing power (FRAP) and $\beta$-carotene/linoleic acid] and vitamin $\mathrm{C}$, of curriola jelly $(\mathrm{p}<0.05)$, stored under room conditions $\left(20.8^{\circ} \mathrm{C} \pm 2.87\right.$ and $\left.69.6 \% \mathrm{RH} \pm 10.51\right)$ for one year. 
activity was observed during the twelve months of storage, emphasizing the lower antioxidant activity. The total reductions in antioxidant capacity determined by the ABTS, DPPH and FRAP methods, at the end of storage was $50 \%$ and $28 \%$. According to Patras et al. (2011), the reduction of antioxidant capacity of jam over the storage period may be attributed to the degradation of vitamin C. Similar results to Patras et al. (2011), regarding the decline in the antioxidant capacity (DPPH $\mathrm{IC}_{50}$ ) of strawberry jam stored for 28 days and those found by Damiani et al. (2012b), in the aqueous and ethanolic extracts of araça jam (Psidium guineensis Sw.) during twelve months of storage.

The average antioxidant activity determined using the phosphomolybdenum complex method was $391.87 \pm 48.46 \mathrm{mg}$ ascorbic acid $100 \mathrm{~g}^{-1}$ and it was not influenced by the studied factors.

The antioxidant evaluation according to the $\beta$-carotene/linoleic acid method is based on measuring the antioxidant capacity to prevent the oxidation of $\beta$-carotene, protecting it from the free radicals formed during the peroxidation of linoleic acid. Figure 1 show cubic adjustments related to the significant interaction $(p<0.05)$ between the analysed factors (packaging and storage
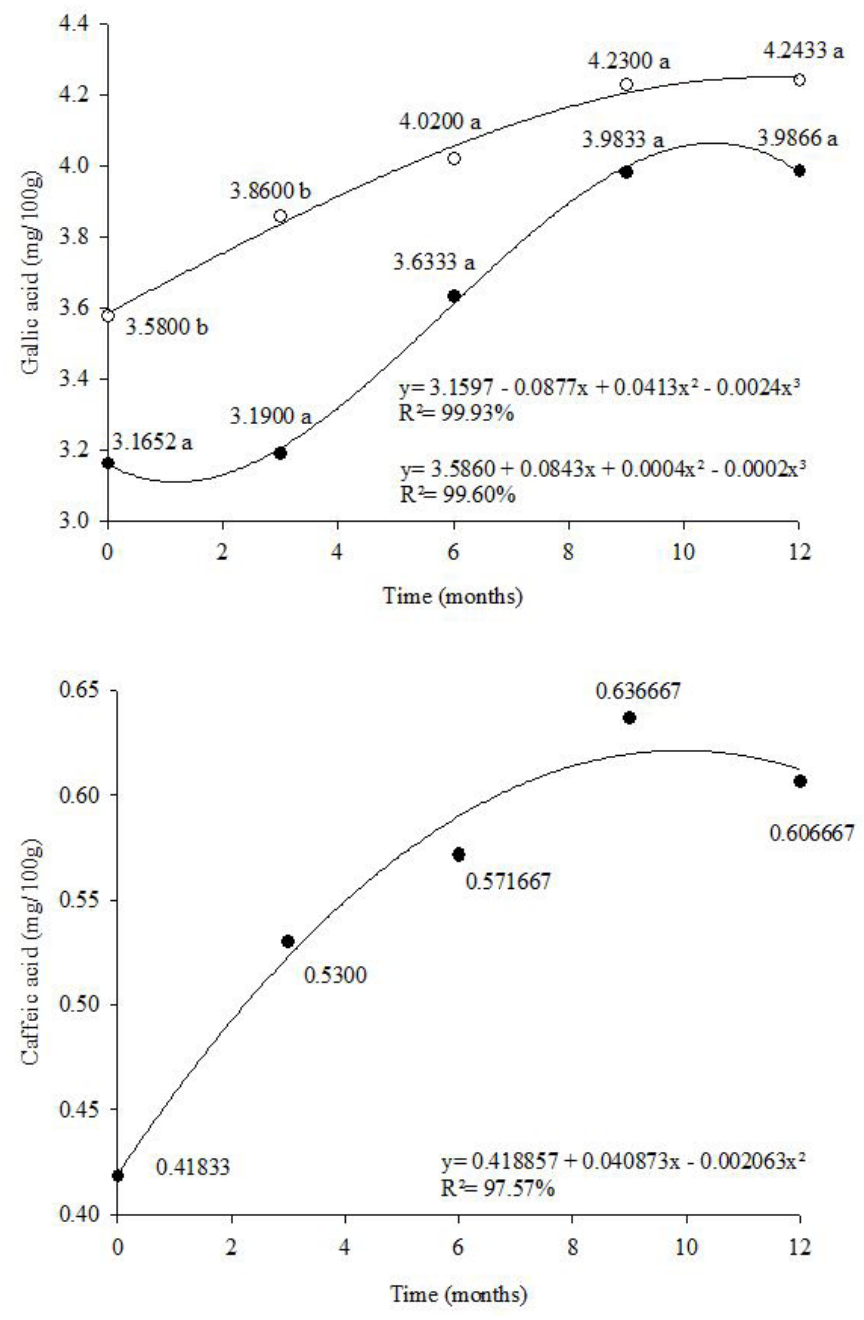

period). In the packaging, the jelly showed the highest oxidation percentage values in the $3^{\text {rd }}, 9^{\text {th }}$, and $12^{\text {th }}$ month when compared with the jellies packed in amber. Qu et al. (2012) investigated the storage stability of phenolic compounds in the extracts of pomegranate peel at $4{ }^{\circ} \mathrm{C}$ under conditions with or without the light incidence. These authors reported a higher degradation of bioactive compounds (vitamin C and polyphenols) even during storage at low temperatures, mainly because of oxidation and polymerization reactions induced by exposure to light; this is corroborated by the results obtained in the present study.

Figure 2 shows the adjustments to the polynomial models due to changes in the individual behavior of the phenolic compounds during storage.

Chlorogenic acid, caffeic acid and vanillin were significantly affected $(p<0.05)$ only by the storage period, whereas a significant interaction was observed $(p<0.05)$ between the packing and storage period factors for the major compound, gallic acid.

Usually, phenolic acids of the non-flavonoid type exist in the plant kingdom in the form of esters, such as gallic acid, chlorogenic acid, and caffeic acid, and they can be found in the form of glycosides or bound to proteins and other cell wall
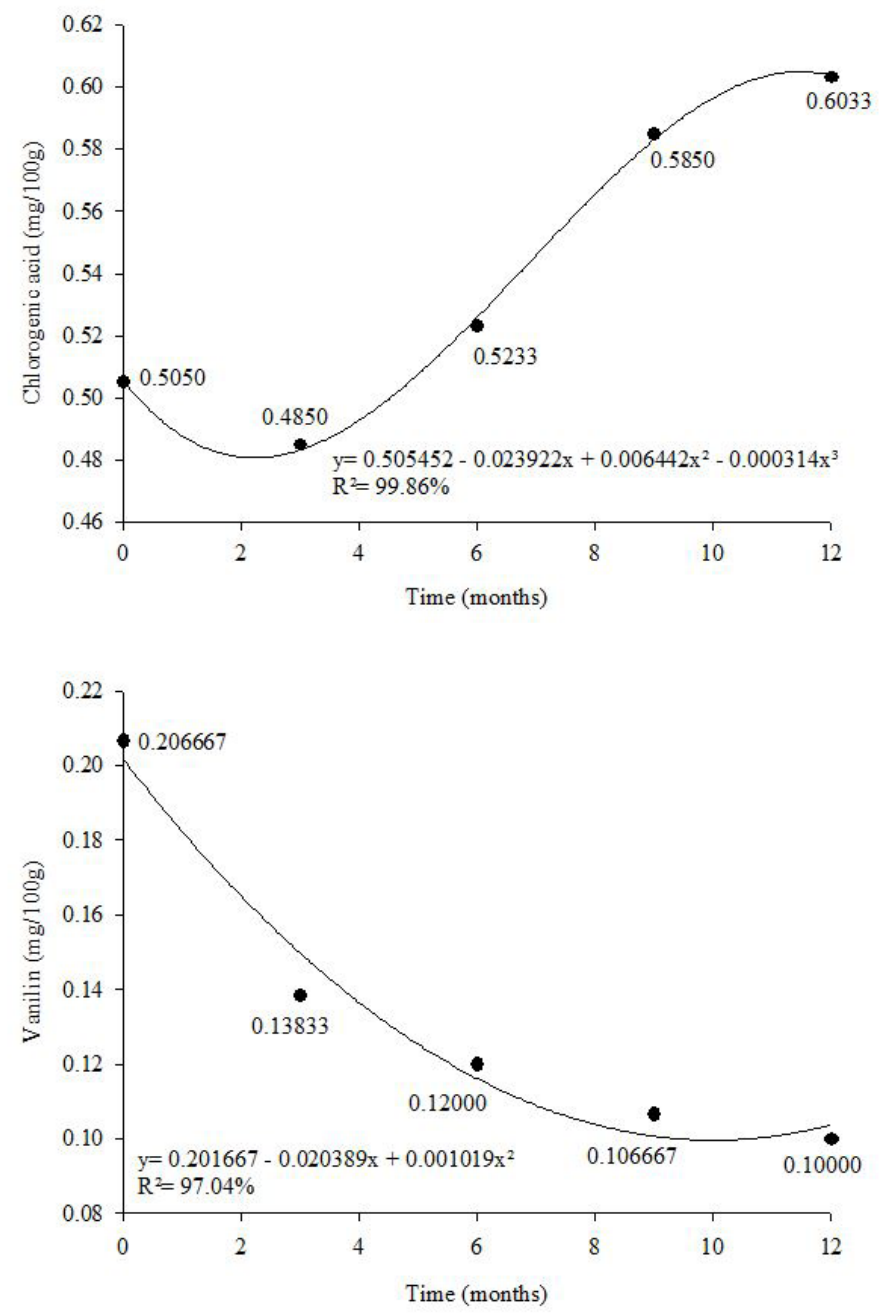

Figure 2. Behavior of phenolic compounds during the storage time $(\mathrm{p}<0.05)$ identified by HPLC-DAD/UV-Vis of the curriola jelly stored under room conditions $\left(20.8^{\circ} \mathrm{C} \pm 2.87\right.$ and $\left.69.6 \% \mathrm{RH} \pm 10.51\right)$ for one year. 

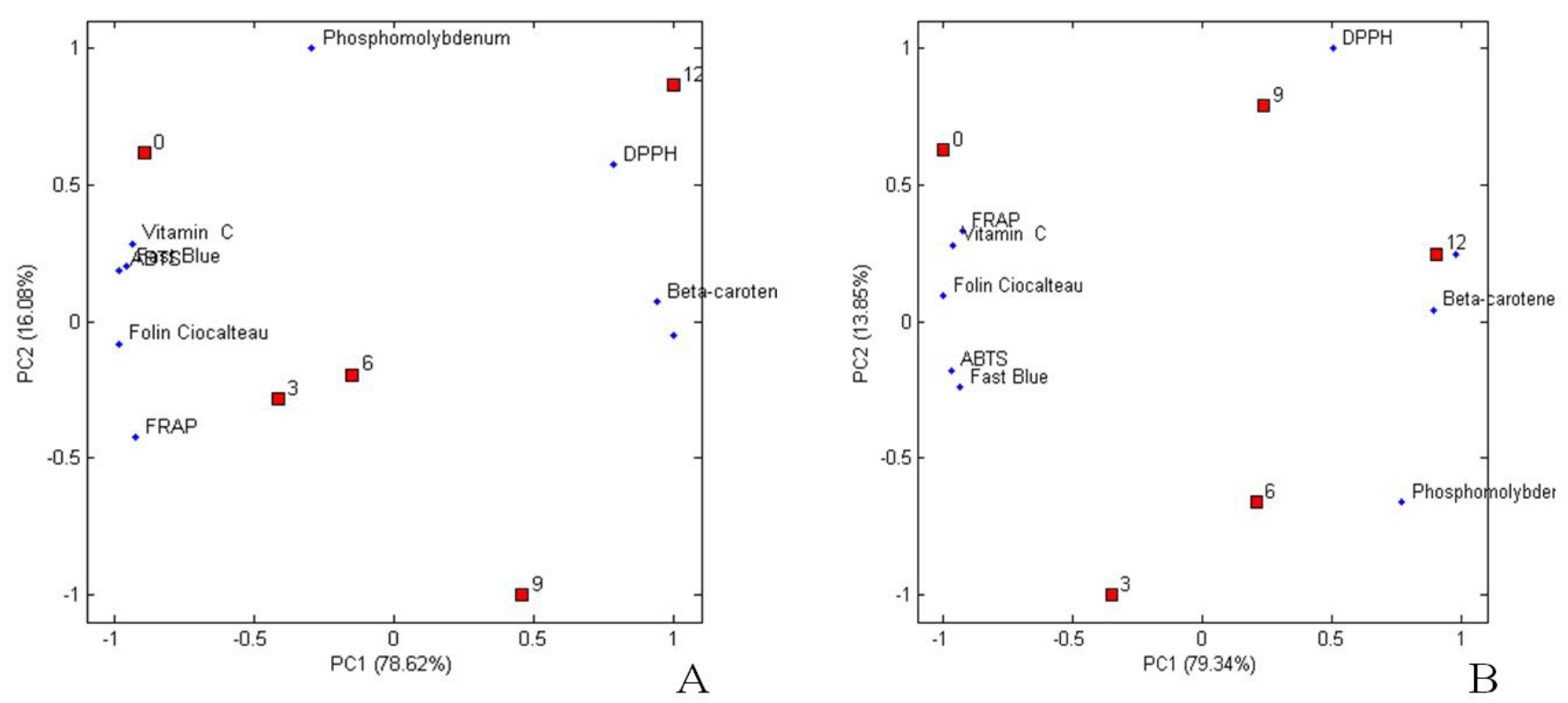

Figure 3. Principal component analysis (PCA) for different antioxidant analysis methods (ABTS, DPPH, $\beta$-carotene/linoleic acid, FRAP and phosphomolybdenum complex) of different phenolic compounds determination methods (Folin-Ciocalteau and Fast Blue) and vitamin $\mathrm{C}$, between the different packages (A) transparent and (B) amber. The storage time (0,3, 6, 9 and 12 months) is represented by squares.

polymers (Degáspari \& Waszczynskyj, 2004). Therefore, an increase in the adjustment of the mathematical model $(p<0.05)$ during the storage period was observed for these polyphenols (Figure 2).

According to Degáspari \& Waszczynskyj (2004), simple polyphenol blends are widely distributed in the plant kingdom. Consequently, the marked tendency observed in the concentrations of gallic acid, chlorogenic acid, and caffeic acid could be attributed to the processing conditions (extraction of complexed phenolic compounds) and storage conditions (gradual release of the complexed phenolic compounds) during the storage period. In case of gallic acid, the jelly was packed using packaging with a light barrier, resulting in the high retention of this phenolic compound during the storage period. The results obtained in the present study corroborate those reported by Zafrilla et al. (2001), who evaluated the effects of the antioxidant capacity of ellagic acid derivatives during the storage of raspberry jam and observed that the content of this product tended to increase during six months of storage, probably because of the gradual release of ellagic acid through ellagitannins present in the jelly after the heat treatment. In the case of vanillin (Figure 2), the significant reduction $(p<0.05)$ during the twelve months of storage, as discussed above, occurred mainly by the oxidation or degradation of this compound under the storage conditions and exposure to light and environmental conditions.

The results of the multivariate analysis of the main components related to the antioxidant capacity, phenolic compounds and vitamin $\mathrm{C}$ among the different packaging treatments (with and without light incidence) are shown in Figure 3. For both packaging treatments (transparent and amber packaging), similar behavior of the samples was observed. The first major component of both treatments packing (Figure 3a and 3b) explains 78 and $79 \%$ of the variability between the samples.
The samples on the first months of storage ( 0,3 and 6 months) were distinct when compared with those on the final period of storage. Therefore, the content of phenolic compounds and antioxidant capacity determined by FRAP and ABTS, besides vitamin $\mathrm{C}$ content, were relatively higher on the first 6 months of storage, whereas the highest results for antioxidant capacity determined by the DPPH IC $\mathrm{IC}_{50}$ and $\beta$-carotene/linoleic acid methods were detected on the ninth and twelfth months of storage.

\section{Conclusion}

The processing of curriola pulp resulted in a slight increase in the bioactive compounds, according to the phenolic compound contents and different methods of antioxidant analysis; only the average levels of vitamin $\mathrm{C}$ were reduced in the freshly prepared jelly.

The significant interaction $(p<0.05)$ between the packaging factor without light incidence and storage time promoted higher bioactive compounds retention, mainly gallic acid retention, and reduced the curriola jelly oxidation percentage, determined by the antioxidant $\beta$-carotene/linoleic acid method.

The storage period significantly influenced $(p<0.05)$ curriola jelly quality, promoting decline in its phenolic compounds and vitamin $\mathrm{C}$ and consequently reduction in its antioxidant capacity.

\section{Acknowledgements}

The authors thank CAPES - Coordination for the Improvement of Higher Education Personnel (88881.068456/2014-01), CNPq - National Council for Scientific and Technological Development (304724/2013-0), and FAPEMIG - Foundation for Research Support of the State of Minas Gerais (PPM-00458-15) for their financial support. 


\section{References}

Al Juhaimi, F., Ozcan, M. M., Uslu, N., Ghafoor, K., \& Babiker, E. E. (2018). Effect of microwave heating on phenolic compounds of prickly pear (Opuntia ficus-indica L.) seeds. Journal of Food Processing and Preservation, 42(2), e13437. http://dx.doi.org/10.1111/jfpp.13437.

Aslanova, D., Bakkalbasi, E., \& Artik, N. (2010). Effect of storage on 5-hydroxymethylfurfural (HMF) formation and color change in jams. International Journal of Food Properties, 13(4), 904-912. http:// dx.doi.org/10.1080/10942910902908896.

Azeredo, H. M. C., Brito, E. S., \& Garruti, D. S. (2012). Alterações químicas durante a estocagem. In H. M. C. Azeredo (Ed.), Fundamentos de estabilidade de alimentos. Brasília: Livraria Embrapa.

Bertin, R. L., Schulz, M., \& Amante, E. R. (2016). Estabilidade de vitaminas no processamento de alimentos: uma revisão. Boletim CEPPA, 34(2), 1-13.

Brand-Williams, W., Cuvelier, M. E., \& Berset, C. (1995). Use of a free radical method to evaluate antioxidant activity. LebensmittelWissenschaft + Technologie, 28(1), 25-30. http://dx.doi.org/10.1016/ S0023-6438(95)80008-5.

Brasil. Ministério da Saúde. Agência Nacional de Vigilância Sanitária - ANVISA. (1978, Julho 24). Resolução - CNNPA nº 12, de 1978. Diário Oficial [da] República Federativa do Brasil.

Chamorro, S., Goñi, I., Viveros, A., Hervert-Hernández, D., \& Brenes, A. (2012). Changes in polyphenolic content and antioxidant activity after thermal treatments of grape seed extract and grape pomace. European Food Research and Technology, 234(1), 147-155. http:// dx.doi.org/10.1007/s00217-011-1621-7.

Damiani, C., Asquieri, E. R., Lage, M. E., Oliveira, R. A., Silva, F. A., Pereira, D. E. P., \& Vilas Boas, E. V. B. (2012a). Study of the shelflife of a mixed araça (Psidium guineensis Sw.) and marolo (Annona crassiflora Mart.) jam. Food Science and Technology (Campinas), 32(2), 334-343. http://dx.doi.org/10.1590/S0101-20612012005000050.

Damiani, C., Silva, A. F., Asquieri, E. R., Lage, E., \& Vilas Boas, E. V. B. (2012b). Antioxidant potential of Psidium guinnensis Sw. jam during storage. Pesquisa Agropecuária Tropical, 42(1), 90-98. http:// dx.doi.org/10.1590/S1983-40632012000100013.

Degáspari, C. H., \& Waszczynskyj, N. (2004). Propriedades antioxidantes de compostos fenólicos. Visão Acadêmica, 5(1), 33-40.

Ferreira, D. F. (2011). SISVAR: A computer statistical analysis system. Ciência e Agrotecnologia, 35(6), 1039-1042. http://dx.doi.org/10.1590/ S1413-70542011000600001.

Fontes, E. A., Souza, P. J. C., Nascimento, J. L. M., Santos, S. N., Espíndola, L. S., \& Ferreira, V. M. M. (2009). Antinociceptive and antiinflammatory properties of the ethanolic extract of Pouteria ramiflora roots. Latin American Journal of Pharmacy, 28(6), 812-818.

Geőcze, K. C., Barbosa, L. C. A., Fidêncio, P. H., Silvério, F. O., Lima, C. F., Barbosa, M. C. A., \& Ismail, F. M. D. (2013). Essential oils from pequi fruits from the Brazilian Cerrado ecosystem. Food Research International, 54(1), 1-8. http://dx.doi.org/10.1016/j. foodres.2013.06.005.

Gu, F., Huang, F., Wu, G., \& Zhu, H. (2018). Contribution of polyphenol oxidation, chlorophyll and vitamin $\mathrm{C}$ degradation to the blackening of Piper nigrum L. Molecules (Basel, Switzerland), 23(2), 1-12. http:// dx.doi.org/10.3390/molecules23020370. PMid:29425156.

Kim, S. Y., Jeong, S. M., Park, W. P., Nam, K. C., Ahn, D. U., \& Lee, S. C. (2006). Effect of heating conditions of grape seeds on the antioxidant activity of grape seed extracts. Food Chemistry, 97(3), 472-479. http://dx.doi.org/10.1016/j.foodchem.2005.05.027.
Kirk, J. R. (1984). Biological availability of nutrients in processed foods. Journal of Chemical Education, 61(4), 364-367. http://dx.doi. org/10.1021/ed061p364.

Larrauri, J. A., Rupérez, P., \& Saura-Calixto, F. (1997). Effect of drying temperature on the stability of polyphenols and antioxidant activity of red grape pomace peels. Journal of Agricultural and Food Chemistry, 45(4), 1390-1393. http://dx.doi.org/10.1021/jf960282f.

Li, C. C., Hsu, H. J., Wang, Y. S., Cassidy, J., Sheen, S., \& Liu, S. C. (2017). Effects of heat treatment on the antioxidative and anti-inflammatory properties of orange by-products. Food \& Function, 8(7), 2548-2557. http://dx.doi.org/10.1039/C7FO00188F. PMid:28653733.

Medina, M. B. (2011). Simple and rapid method for the analysis of phenolic compounds in beverages and grains. Journal of Agricultural and Food Chemistry, 59(5), 1565-1571. http://dx.doi.org/10.1021/ jf103711c. PMid:21309564.

Miller, H. E. (1971). A simplified method for the evaluation of antioxidant. Journal of the American Oil Chemists' Society, 48(2), 91. http://dx.doi. org/10.1007/BF02635693.

Miranda, T. G., Lafetá, B. O., Dessimoni-Pinto, N. A. V., \& Vieira, G. (2012). Avaliação do morango em calda submetido a diferentes concentrações de açúcar e condições de armazenamento. Brazilian Journal of Food and Nutrition, 23(2), 307-315.

Morzelle, M. C., Bachiega, P. P., Souza, E. C., Vilas Boas, E. V. B., \& Lamounier, M. L. (2015). Caracterização química e física de frutos de curriola, gabiroba e murici provenientes do Cerrado brasileiro. Revista Brasileira de Fruticultura, 37(1), 96-103. http://dx.doi. org/10.1590/0100-2945-036/14.

Nunes, C. A., Freitas, M. P., Pinheiro, A. C. M., \& Bastos, S. C. (2012). Chemoface: A novel free user-friendly interface for chemometrics. Journal of the Brazilian Chemical Society, 23(11), 2003-2010. http:// dx.doi.org/10.1590/S0103-50532012005000073.

Ozcan, M. M., \& Uslu, N. (2017). Effect of drying on antioxidant activity, total phenol, mineral contents and phenolic compounds of guava (Psidium guajava L.) fruit. Zeitschrift für Arznei-\& Gewürzpflanzen, 22(3), 125-128.

Papoutsis, K., Pristijono, P., Golding, J. B., Stathopoulos, C. E., Bowyer, M. C., Scarlett, C. J., \& Voung, Q. V. (2017). Enhancement of the total phenolic compounds and antioxidant activity of aqueous Citrus limon L. pomace extract using microwave pretreatment on the dry powder. Journal of Food Processing and Preservation, 41(5), e13152. http://dx.doi.org/10.1111/jfpp.13152.

Patras, A., Brunton, N. P., Tiwari, B. K., \& Butler, F. (2011). Stability and degradation kinetics of bioative compounds and colour in strawberry jam during storage. Food and Bioprocess Technology, 4(7), 1245-1252. http://dx.doi.org/10.1007/s11947-009-0226-7.

Perfeito, J. P., Santos, M. L., López, K. S. E., Paula, J. E., \& Silveira, D. (2005). Characterization and biological properties of Pouteria torta extracts: a preliminary study. Revista Brasileira de Farmacognosia, 15(3), 183-186. http://dx.doi.org/10.1590/S0102-695X2005000300002.

Prieto, P., Pineda, M., \& Aguilar, M. (1999). Spectrophotometric quantitation of antioxidant capacity through the formation of a phosphomolybdenum complex: specific application to the determination of vitamin E. Analytical Biochemistry, 269(2), 337341. http://dx.doi.org/10.1006/abio.1999.4019. PMid:10222007.

Pulido, R., Bravo, L., \& Saura-Calixto, F. (2000). Antioxidant activity of dietary polyphenols as determined by a modified ferric reducing/ antioxidant power assay. Journal of Agricultural and Food Chemistry, 48(8), 3396-3402. http://dx.doi.org/10.1021/jf9913458. PMid:10956123.

Qu, W., Breksa 3rd, A. P., Pan, Z., Ma, H., \& McHugh, T. H. (2012). Storage stability of sterilized liquid extracts from pomegranate peel. 
Journal of Food Science, 77(7), 765-772. http://dx.doi.org/10.1111/ j.1750-3841.2012.02779.x. PMid:22757697.

Ramaiya, S. D., Bujang, J. S., Zakaria, M. H., King, W. S., \& Shaffiq Sahrir, M. A. (2013). Sugars, ascorbic acid, total phenolic content and total antioxidant activity in passion fruit (Passiflora) cultivars. Journal of the Science of Food and Agriculture, 93(5), 1198-1205. http://dx.doi.org/10.1002/jsfa.5876. PMid:23027609.

Ramful, D., Tarnus, E., Aruoma, O. I., Bourdon, E., \& Bahorun, T. (2011). Polyphenol composition, vitamin C content and antioxidant capacity of Mauritian citrus fruit pulps. Food Research International, 44(7), 2088-2099. http://dx.doi.org/10.1016/j.foodres.2011.03.056.

Raupp, D. S., Rodrigues, E., Rockenbach, I. I., Carbonar, A., Campos, P. F., Borsato, A. V., \& Fett, R. (2011). Effect of processing on antioxidant potential and total phenolics content in beet (Beta vulgaris L.). Food Science and Technology (Campinas), 31(3), 688-693. http://dx.doi. org/10.1590/S0101-20612011000300021.

Rodrigues, P. M., Dutra Gomes, J. V., Jamal, C. M., Cunha Neto, Á., Santos, M. L., Fagg, C. W., Fonseca-Bazzo, Y. M., Magalhães, P. O., de Sales, P. M., \& Silveira, D. (2017). Triterpenes from Pouteria ramiflora (Mart.) Radlk. Leaves (Sapotaceae). Food and Chemical Toxicology, 109(Pt 2), 1063-1068. http://dx.doi.org/10.1016/j. fct.2017.05.026. PMid:28533130.

Roesler, R., Catharino, R. R., Malta, L. G., Eberlin, M. N., \& Pastore, G. G. M. (2008). Antioxidant activity of Caryocar brasiliense (pequi) and characterization of components by electrospray ionization mass spectrometry. Food Chemistry, 110(3), 711-717. http://dx.doi. org/10.1016/j.foodchem.2008.02.048.

Siddhuraju, P., \& Manian, S. (2007). The antioxidant activity and free radical-scavenging capacity of dietary phenolic extracts from horse gram (Macrotyloma uniflorum (Lam.) Verdc.) seeds. Food Chemistry, 105(3), 950-958. http://dx.doi.org/10.1016/j.foodchem.2007.04.040.

Silva, C. A. M., Simeoni, L. A., \& Silveira, D. (2009). Genus pouteria: chemistry and biological activity. Brazilian Journal of Pharmacognosy, 19(2A), 501-509.

Silva, M. A. B., Melo, L. V. L., Ribeiro, R. V., Souza, J. P. M., Lima, J. C. S., Martins, D. T. O., \& Silva, R. M. (2010). Levantamento etnobotânico de plantas utilizadas como anti-hiperlipidêmicas e anorexígenas pela população de Nova Xavantina-MT, Brasil. Brazilian Journal of Pharmacognosy, 20(4), 549-562. http://dx.doi.org/10.1590/S0102695X2010000400014.

Strohecker, R., \& Henning, H. M. (1967). Analisis de vitaminas: metodos comprovados. Madrid: Paz Montolvo.

Sun, H. N., Mu, T. H., \& Xi, L. S. (2017). Effect of pH, heat, and light treatments on the antioxidant activity of sweet potato leaf polyphenols. International Journal of Food Properties, 20(2), 318-332. http://dx.doi. org/10.1080/10942912.2016.1160410.

Touati, N., Tarazona-Díaz, M. P., Aguayo, E., \& Louaileche, H. (2014). Effect of storage time and temperature on the physicochemical and sensory characteristics of commercial apricot jam. Food Chemistry, 145, 23-27. http://dx.doi.org/10.1016/j.foodchem.2013.08.037. PMid:24128444.

Vasco, C., Ruales, J., \& Kamal-Eldin, A. (2008). Total phenolic compounds and antioxidant capacities of major fruits from Ecuador. Food Chemistry, 111(4), 816-823. http://dx.doi.org/10.1016/j.foodchem.2008.04.054.

Viana, E. S., Jesus, J. L., Reis, R. C., Fonseca, M. D., \& Sacramento, C. K. (2012). Caracterização físico-química e sensorial de geleia de mamão com araçá-boi. Revista Brasileira de Fruticultura, 34(4), 1154-1164. http://dx.doi.org/10.1590/S0100-29452012000400024.

Waterhouse, A. L. (2002). Determination of total phenolics. Current Protocol in Food Analytical Chemistry, 11(1), 130-143.

Zafrilla, P., Ferreres, F., \& Tomás-Barberán, F. A. (2001). Effect of processing and storage on the antioxidant ellagic acid derivatives and flavonoids of red raspberry (Rubus idaeus) jams. Journal of Agricultural and Food Chemistry, 49(8), 3651-3655. http://dx.doi. org/10.1021/jf010192x. PMid:11513642.

Zulueta, A., Barba, F. J., Esteve, M. J., \& Frígola, A. (2013). Changes in quality and nutritional parameters during refrigerated storage of an orange juice-milk beverage treated by equivalent thermal and non-thermal processes for mild pasteurization. Food and Bioprocess Technology, 6(8), 2018-2030. http://dx.doi.org/10.1007/ s11947-012-0858-X. 